\title{
The Competitiveness of Chinese Commercial Banks in New Period
}

\author{
Jing Wang ${ }^{1,2, ~ a ~, ~ J i a n h o n g ~ S u n ~}{ }^{1, b}$, \\ ${ }^{1}$ Shaanxi Provincial Land Engineering Construction Group Co., Ltd., Institute of Land Engineering \\ and Technology, Shaanxi Provincial Land Engineering Construction Group, Co. Ltd., Key \\ Laboratory of Degraded and Unused Land Consolidation Engineering, the Ministry of Land and \\ Resources, Xi'an 710075, China \\ ${ }^{2}$ Xi'an University of Technology, Xi'an 710048, China \\ awangjing0722@126.com, ${ }^{\text {a } 401322697 @ q q . c o m ~}$
}

Keywords: bank; competitive; capital; profit; risk

\begin{abstract}
As Chinese financial market moves into the new normal, the competition and challenges faced by commercial banks are becoming increasingly severe. It is of great significance to improve the competitive strength of all banking industry. This paper selects 16 banks of three types, analyzes the differences between different types of commercial banks from the aspects of capital status, profitability, capital cost and risk management, and uses factor analysis methods to rank the comprehensive competitiveness of the 16 banks. It provides theoretical guidance and scientific basis for the improvement of the comprehensive competitiveness of banks in China.
\end{abstract}

\section{Introduction}

As Chinese financial market moves into the new normal, under the influence of the slowdown in macroeconomic growth, financial disintermediation, interest rate liberalization and internet financial shocks, traditional commercial banks will not only face severe challenges from foreign banks, but also have been faced with the strong internet finance in all aspects of their businesses [1,2]. The strong impact has made the commercial banks face greater competition and challenges. Therefore, how to correctly evaluate the competitiveness of banks in the new era and the new normal, with a view to finding ways to improve on this basis and responding to different challenges, become the focus of the banking industry, and the overall competitiveness and sustainable management of listed banks. It has extremely important significance.

\section{Comparison of the Competitiveness of Commercial Banks}

This paper selected 16 listed banks to analyze the competitiveness level of China's banking industry, including 5 state-owned commercial banks: Industrial and Commercial Bank of China, 
Agricultural Bank of China, China Construction Bank, Bank of China, and Bank of Communications; 8 joint-stock commercial banks: China Merchants Bank, Shanghai Pudong Development Bank, CITIC Bank, Minsheng Bank, Huaxia Bank, Everbright Bank, Ping An Bank, Industrial Bank; and 3 city commercial banks: Beijing Bank, Nanjing Bank, and Ningbo Bank.

\subsection{Capital Status}

Better capitalized banks would be more resilient [3]. We uses the leverage ratio to measure the capital status of the bank. Leverage ratio refers to the ratio of the first tier capital of commercial banks to the adjusted balance of assets inside and outside the bank. The higher leverage ratio indicates that the more sufficient capital and the stronger ability to resist risks [4].

Table 1 Leverage of 16 banks

\begin{tabular}{cc}
\hline Bank & Leverage $(\%)$ \\
\hline Industrial and Commercial Bank & 7.55 \\
Agricultural Bank & 6.27 \\
Construction Bank & 7.03 \\
Bank of China & 7.06 \\
Bank of Communications & 6.65 \\
China Merchants Bank & 5.75 \\
Shanghai Pudong Development Bank & 5.47 \\
China CITIC Bank & 5.47 \\
Minsheng Bank & 5.19 \\
Huaxia Bank & 5.61 \\
Everbright Bank & 5.44 \\
Ping An Bank & 5.49 \\
Industrial Bank & 5.25 \\
Beijing Bank & 5.75 \\
Nanjing Bank & 5.25 \\
Ningbo Bank & 5.08 \\
\hline
\end{tabular}

From the data of leverage, we can see that large-scale state-owned commercial banks are relatively conservative. ICBC, Construction Bank and the Bank of China have the highest leverage ratios of more than 7\%. Small and medium-scale banks have lower leverage ratios. The China Merchants Bank is the highest among the joint-stock commercial banks, while the Ningbo bank in the city commercial banks is the most aggressive, with a leverage ratio of $5.08 \%$ and a highest risk.

\subsection{Profitability}

The return on assets is the percentage of the profits and average shareholders' equity of commercial banks [5]. This indicator measures the efficiency of commercial banks in using their own capital. The higher the rate of return on assets, the higher the return to shareholders from the company investment, and the stronger the profitability [6,7].

From the average data of 2014-2016, benefiting from the scale advantages, the ROA of state-owned commercial banks was higher than that of joint-stock commercial banks. ICBC and CCB were the highest with strong profitability. China Merchants Bank has the strongest profitability in joint-stock commercial banks. It is already at the same level as state-owned commercial banks. The ROA of Ping an Bank is only 0.85\%, which is the lowest among 16 banks. Although the city commercial banks have lower profits, ROA was in the middle because of their relatively small total assets. 
Table 2 The ROA and ROE of 16 banks

\begin{tabular}{ccccccccc}
\hline \multirow{2}{*}{ Bank } & \multicolumn{4}{c}{ ROA (\%) } & \multicolumn{5}{c}{ ROE (\%) } \\
\cline { 2 - 9 } & 2014 & 2015 & 2016 & Average & 2014 & 2015 & 2016 & Average \\
\hline Industrial and & 1.40 & 1.30 & 1.20 & 1.30 & 19.96 & 17.10 & 15.24 & 17.43 \\
Commercial Bank & & & & & & & & \\
Agricultural Bank & 1.18 & 1.07 & 0.99 & 1.08 & 19.57 & 16.79 & 15.14 & 17.17 \\
Construction Bank & 1.42 & 1.30 & 1.18 & 1.30 & 19.74 & 17.27 & 15.44 & 17.48 \\
Bank of China & 1.22 & 1.12 & 1.05 & 1.13 & 17.28 & 14.53 & 12.58 & 14.80 \\
Bank of & 1.08 & 1.00 & 0.87 & 0.98 & 14.87 & 13.46 & 12.22 & 13.52 \\
Communications & & & & & & & \\
China Merchants Bank & 1.28 & 1.13 & 1.09 & 1.17 & 19.28 & 17.09 & 16.27 & 17.55 \\
Shanghai Pudong & 1.20 & 1.10 & 0.98 & 1.09 & 21.02 & 18.82 & 16.35 & 18.73 \\
Development Bank & & & & & & & \\
China CITIC Bank & 1.07 & 0.90 & 0.76 & 0.91 & 16.84 & 14.55 & 12.58 & 14.66 \\
Minsheng Bank & 1.26 & 1.10 & 0.94 & 1.10 & 20.41 & 16.98 & 15.13 & 17.51 \\
Huaxia Bank & 1.02 & 0.98 & 0.90 & 0.97 & 19.31 & 17.18 & 15.75 & 17.41 \\
Everbright Bank & 1.12 & 1.00 & 0.85 & 0.99 & 17.36 & 15.50 & 13.80 & 15.55 \\
Ping An Bank & 0.91 & 0.87 & 0.77 & 0.85 & 16.35 & 14.94 & 13.18 & 14.82 \\
Industrial Bank & 1.18 & 1.04 & 0.95 & 1.06 & 21.21 & 18.89 & 17.28 & 19.13 \\
Beijing Bank & 1.09 & 1.00 & 0.90 & 1.00 & 17.98 & 16.26 & 14.92 & 16.39 \\
Nanjing Bank & 1.12 & 1.02 & 0.88 & 1.01 & 19.00 & 17.59 & 16.25 & 17.61 \\
Ningbo Bank & 1.11 & 1.03 & 0.98 & 1.04 & 19.45 & 17.68 & 17.74 & 18.29 \\
\hline
\end{tabular}

For ROE, joint-stock commercial banks such as Industrial Bank, Shanghai Pudong Development Bank and Ningbo Bank are relatively high. The advantages of state-owned banks in terms of ROA are not reflected in ROE. The ROE of Bank of China and Bank of Communications is the lowest among all banks. The reason probably was the supervision by the China Banking Regulatory Commission for state-owned banks is stricter than that of joint-stock commercial banks. As a result, the net asset rate is high, which leads to a low return on net assets at the same level of capital consumption. Industrial Bank's impressive data is high due to the development of its interbank business which consumes less capital.

Generally speaking, the return on assets of all commercial banks has been on a downward trend in the past three years, indicating that the internet finance has a significant impact on the entire banking industry.

\subsection{Capital Cost}

Demand deposits have the lowest interest rate and therefore the lowest capital cost of all deposits types. Among the joint-stock commercial banks, China Merchants Bank has the highest demand deposit rate of 62.94\%, and the capital cost is much lower than other banks. China Merchants Bank has benefited from its unremitting efforts in retail business in recent years, sticky attracting a large number of customers with lucrative credit card businesses, wealth management products and high-quality services, so the capital cost is far ahead not only of joint-stock commercial banks, but also state-owned commercial banks.

By absorbing a large amount of current deposits, a good bank has a low-cost capital source thus obtaining a lower debt cost than the other banks in the era of interest rate marketization. Of course, Due to their multiple outlets and facilities, large-scale banks such as the Agricultural Bank and Construction Bank still maintain a leading position in the capital cost by having absorbed many savings deposits. However, although retail deposits account for a relatively high percentage, their 
customer base cannot be compared with China Merchants Bank. Most of the deposit customers are mostly small deposit customers, which has high maintenance costs and low returns.

Table 3 Current savings rate and non-interest income of 16 banks

\begin{tabular}{ccc}
\hline Bank & Current savings rate $(\%)$ & Non-interest income (\%) \\
\hline Industrial and Commercial & 50.44 & 30.19 \\
Bank & 55.90 & 21.33 \\
Agricultural Bank & 54.45 & 30.95 \\
Construction Bank & 44.53 & 36.72 \\
Bank of China & 51.77 & 19.05 \\
Bank of Communications & 62.94 & 35.61 \\
China Merchants Bank & 45.83 & 32.76 \\
Shanghai Pudong & 52.90 & 31.00 \\
Development Bank & 42.46 & 39.00 \\
China CITIC Bank & 49.31 & 23.48 \\
Minsheng Bank & 42.87 & 29.89 \\
Huaxia Bank & 41.52 & 29.06 \\
Everbright Bank & 43.97 & 28.49 \\
Ping An Bank & 50.79 & 20.93 \\
Industrial Bank & 35.15 & 20.25 \\
Beijing Bank & 50.75 & 27.85 \\
Nanjing Bank & Nank & \\
Ningbo Bank & & \\
\hline
\end{tabular}

Non-interest income is mainly generated by intermediate business income, and activities such as consultation and investment. Compared with interest income, non-interest income businesses are relatively stable, secure, and generally have higher profit margins. There is no obvious boundary between the state-owned banks and joint-stock commercial banks of this index. Bank of China, because of its leading external business, China Merchants Bank and Minsheng Bank have higher non-interest income due to their efforts to expand their wealth management, credit card and continuously improving intermediary business. The data of Agricultural Bank, Bank of Communications and two city commercial banks, Beijing Bank and Nanjing Bank have poor performance. It was mainly due to the fact that their business was still mainly absorbed by deposits and loans, so the proportion of interest income was still high, and its asset structure was heavy.

Generally speaking, "light banks" with more flexible mechanisms can easily carry out other financial services to increase non-interest income. This kind of light asset development mode is also the objective of commercial banks' transformation under the impact of Internet finance.

\subsection{Risk Management}

The non-performing loan rate affects asset quality of commercial banks. It is a negative indicator. The lower the non-performing loan rate, the less the risk of loan recovery. The People's Bank of China stipulates that the non-performing loan ratio must not exceed 25\%.

From the above data, it can be seen that the non-performing loan rate of city commercial banks is the lowest among all banks. The data of Nanjing Bank and Ningbo Bank are less than 1. It may be because the narrow business area which mainly concentrated in the head office and its radiation area of city commercial banks. Through strengthening the corporate governance, risk control is better. The Agricultural Bank has the highest non-performing loans, which is far beyond the other banks and is close to the standards set by the People's Bank of China. This probably because the Agricultural Bank 
has more agricultural customers for public loans, which makes banks more passive in assets. The wider geographical distribution also makes it more difficult for large-scale commercial banks to control risks than city commercial banks, so the non-performing loan ratio is relatively high.

Table 4 Non-performing loan ratio of 16 banks

\begin{tabular}{cc}
\hline Bank & Non-performing loan ratio (\%) \\
\hline Industrial and Commercial Bank & 1.62 \\
Agricultural Bank & 2.37 \\
Construction Bank & 1.52 \\
Bank of China & 1.46 \\
Bank of Communications & 1.52 \\
China Merchants Bank & 1.87 \\
Shanghai Pudong Development Bank & 1.89 \\
China CITIC Bank & 1.69 \\
Minsheng Bank & 1.68 \\
Huaxia Bank & 1.67 \\
Everbright Bank & 1.6 \\
Ping An Bank & 1.74 \\
Industrial Bank & 1.65 \\
Beijing Bank & 1.27 \\
Nanjing Bank & 0.87 \\
Ningbo Bank & 0.91 \\
\hline
\end{tabular}

\section{Comprehensive Ranking of Listed Bank Competitiveness}

Table 5 Comprehensive ranking of 16 banks

\begin{tabular}{|c|c|c|c|c|c|c|}
\hline Rank & Bank & $\mathrm{F} 1$ & $\mathrm{~F} 2$ & F3 & F4 & $\mathrm{F}$ \\
\hline 1 & China Merchants Bank & 0.28197 & 1.64476 & 0.85462 & 0.58048 & 0.74619 \\
\hline 2 & Construction Bank & 1.87117 & 0.05893 & 0.58949 & 0.08377 & 0.68337 \\
\hline 3 & $\begin{array}{l}\text { Industrial and Commercial } \\
\text { Bank }\end{array}$ & 2.16632 & -0.15557 & 0.28073 & 0.19019 & 0.67214 \\
\hline 4 & Agricultural Bank & 0.03094 & 2.09885 & 0.26110 & -1.00818 & 0.36934 \\
\hline 5 & $\begin{array}{l}\text { Shanghai Pudong } \\
\text { Development Bank }\end{array}$ & -0.44882 & 0.36088 & 1.08545 & 0.86213 & 0.33887 \\
\hline 6 & Bank of China & 1.30201 & -0.88464 & -1.37374 & 1.44574 & 0.13902 \\
\hline 7 & Industrial Bank & -0.59320 & -0.15112 & 1.39479 & 0.14247 & 0.11301 \\
\hline 8 & Minsheng Bank & -1.07671 & -0.25825 & 0.16733 & 1.84729 & 0.00316 \\
\hline 9 & Ningbo Bank & -0.22100 & -0.92800 & 1.32144 & -0.64029 & -0.11901 \\
\hline 10 & China CITIC Bank & -0.72671 & 0.65953 & -1.08607 & 0.29914 & -0.22533 \\
\hline 11 & Everbright Bank & -0.54469 & -0.38876 & -0.63723 & 0.53703 & -0.28095 \\
\hline 12 & Huaxia Bank & -0.72567 & 0.40581 & -0.19964 & -0.79300 & -0.29681 \\
\hline 13 & Bank of Communications & 0.60396 & 0.13908 & -1.74657 & -1.49892 & -0.43154 \\
\hline 14 & Beijing Bank & -0.55382 & -0.16906 & -0.24252 & -1.50357 & -0.51929 \\
\hline 15 & Ping An Bank & -1.07853 & -0.15762 & -1.34242 & 0.52314 & -0.52840 \\
\hline 16 & Nanjing Bank & -0.28724 & -2.27482 & 0.67324 & -1.06741 & -0.66377 \\
\hline
\end{tabular}

Using SPSS17.0 software, factor analysis was performed on the above index data of 16 listed banks. Firstly, the positive and dimensionless processing of the index data has been carried out to 
eliminate the influence of the reverse index and the different measurement units. According to the selected variable and the calculation formula, the score and ranking of each commercial bank on each factor are calculated [8-10]. The comprehensive ranking is shown in the following table.

According to the comprehensive evaluation F, in general, large state-owned commercial banks, in addition to Bank of Communications, rely on the leading position in corporate business and retail business, and are ranked in the front position, maintaining their competitive advantages over their peers. The outstanding shares in joint-stock commercial banks no longer inferior their competitiveness in large-scale state-owned commercial banks, especially China Merchants Bank, shows the strongest competitiveness with the strongest deposit absorption capacity, the lowest capital cost, moderate asset returns, and relatively consistent policy continuity in risk control. Because of the characteristics of business region, there is still a gap between the city commercial banks and the state-owned banks and joint-stock commercial banks, and the ranking is behind. However, as the small bank, the Ningbo Bank shows great development potential by virtue of their advantageous profit structure and risk management capabilities, ranking in the middle among all banks.

\section{Conclusion}

At present, large-scale state-owned commercial banks still occupy a dominant position in China's banking system. They have an advantage in market scale and asset quality, which can be effectively transformed into market competitiveness. However, its risk management is insufficient and the management efficiency is low. Therefore, in the face of increasingly fierce competition, the competitiveness of state-owned banks can be improved only by actively promoting the institutional reform, reconstructing the management mode and improving management efficiency.

With the advantages of flexible operating mechanism and short management radius, joint-stock commercial banks react quickly to the individual needs of customers. They have shorter product innovation and development cycles, higher service quality and efficiency, and their market share continues to expand. In recent years, joint-stock commercial banks have increasingly focused on nurturing and enhancing their core competitiveness. The differential operation of some banks has formed a characteristic.

Although there is a significant gap between city commercial banks and large banks in terms of scale, asset quality, and so on, through strengthening corporate governance and improving their operational management, asset scales of city commercial banks have also grown faster, and their competitiveness in regional markets has also continued to increase.

In a word, each listed bank should weigh its advantages and disadvantages, find the reasons and improve the weak links, consolidate the advantages, and realize the development and improve competitiveness as a whole. At the same time, in the face of the impact of Internet finance, banks should accelerate the pace of business innovation, layout mobile Internet e-finance business, make full efforts to build the online mall, use big data to provide personalized services for customers, and further increase the transformation and upgrading of the bank.

\section{References}

[1] Mao Xiaohong, Gao Dan. 2016. An empirical analysis of the competitiveness of China's commercial banks and its influencing factors under the new normal: Take 12 banks as an example. New West: Late Theory, Vol.12(69-70).

[2] M.J. Farrell. 1957. The measurement of productive effciency, Journal of the Royal Statistical Society.

[3] Wang Songqi, Liu Yihui, Ou Minggang. 2017.Evaluation report on the competitiveness of China commercial bank in 2017 (Abstract). Banker, Vol.9.

[4] Xin Zhen, Zhou Xuemei. 2017. Study on the competitiveness of China's listed large and medium-sized joint-stock commercial banks. China's Collective Economy, Vol. 26(10-12). 
[5] Jia Hongwen, Li Wei. 2013. Empirical study on the relationship between profitability and risk-taking of commercial banks: An analysis based on the panel data of China's 14 listed banks. Journal of Jilin Institute of Business and Technology, Vol. 29(47-51).

[6] Li Wei. 2013. Analysis of profitability of listed banks based on grey relational analysis. Friends of Accounting, Vol. 4(85-87).

[7] Zhu Weidong, Hu Liu, Li Shaohua et al. 2014. Comparative study of profitability and risk profitability of listed banks: Empirical analysis based on listed state-owned and joint-stock banks. Finance and Accounting Communications, Vol. 6(75-78).

[8] Zhang Zhezhe. 2016. A study on competitiveness of China's commercial banks based on factor analysis. Economist, Vol. 4(81-84).

[9] Zhang Juan. 2016. Influencing factors of profitability of commercial banks: based on data analysis of China's listed banks. Journal of Jiangxi University of Science and Technology, Vol.6 (8).

[10] Fang Xianming, Su Xiaoyu, Sun Li. 2014. Study on the competitiveness level of China's commercial banks: based on the analysis of 16 listed commercial banks in 2010 and 2012. Journal of Central University of Finance and Economics, Vol.3(31-38). 